\title{
Hydrogen/Chlorine Exchange Reactions of Gaseous Carbanions
}

\author{
Hao Chen and R. Graham Cooks \\ Department of Chemistry, Purdue University, West Lafayette, Indiana, USA \\ Eduardo C. Meurer and Marcos N. Eberlin* \\ Institute of Chemistry, State University of Campinas, UNICAMP, Campinas, Brazil
}

Gas-phase reactions of three typical carbanions $\mathrm{CH}_{2} \mathrm{NO}_{2}^{-}, \mathrm{CH}_{2} \mathrm{CN}^{-}$, and $\mathrm{CH}_{2} \mathrm{~S}(\mathrm{O}) \mathrm{CH}_{3}^{-}$with the chloromethanes $\mathrm{CH}_{2} \mathrm{Cl}_{2}, \mathrm{CHCl}_{3}$, and $\mathrm{CCl}_{4}$, examined by tandem mass spectrometry, show a novel hydrogen/chlorine exchange reaction. For example, reaction between the nitromethyl anion $\mathrm{CH}_{2} \mathrm{NO}_{2}^{-}$and carbon tetrachloride $\mathrm{CCl}_{4}$ forms the ion $\mathrm{CHClNO}_{2}^{-}$. The suggested reaction mechanism involves nucleophilic attack by $\mathrm{CH}_{2} \mathrm{NO}_{2}^{-}$at the chlorine of $\mathrm{CCl}_{4}$ followed by proton transfer within the resulting complex $\left[\mathrm{CH}_{2} \mathrm{ClNO}_{2}+\mathrm{CCl}_{3}^{-}\right]$to form $\mathrm{CHClNO}_{2}^{-}$and $\mathrm{CHCl}_{3}$. Two other carbanions $\mathrm{CH}_{2} \mathrm{CN}^{-}$and $\mathrm{CH}_{2} \mathrm{~S}(\mathrm{O}) \mathrm{CH}_{3}^{-}$also undergo the novel hydrogen/ chlorine exchange reactions with $\mathrm{CCl}_{4}$ but to a much smaller extent, their higher nucleophilicities favoring competitive nucleophilic attack reactions. Proton abstraction is the exclusive pathway in the reactions of these carbanions with $\mathrm{CHCl}_{3}$. While $\mathrm{CH}_{2} \mathrm{CN}^{-}$and $\mathrm{CH}_{2} \mathrm{~S}(\mathrm{O}) \mathrm{CH}_{3}^{-}$ promote mainly proton abstraction and nucleophilic displacement in reactions with $\mathrm{CH}_{2} \mathrm{Cl}_{2}$, $\mathrm{CH}_{2} \mathrm{NO}_{2}^{-}$does not react. (J Am Soc Mass Spectrom 2005, 16, 2045-2051) (c) 2005 American Society for Mass Spectrometry

$\mathrm{N}$ itromethyl, cyanomethyl, and dimethylsulfinyl carbanions $\left(\mathrm{CH}_{2} \mathrm{NO}_{2}^{-}, \mathrm{CH}_{2} \mathrm{CN}^{-}\right.$, and $\mathrm{CH}_{2} \mathrm{~S}(\mathrm{O}) \mathrm{CH}_{3}^{-}$) are important reactive intermediates in organic chemistry. Due to the strong electronwithdrawing effect of the nitro, cyano and sulfinyl groups, the negative charge on carbon is delocalized and the stability of these carbanions is enhanced (Scheme 1). The nitromethyl anion $\mathrm{CH}_{2} \mathrm{NO}_{2}^{-}$is believed to be involved in the Henry or nitroaldol reaction, [1] a classic carbon-carbon coupling reaction between an alkylnitro compound bearing $\alpha$ hydrogens and a carbonyl compound. Dimethylsulfinyl carbanions have been used in innumerable synthetic studies since Corey and Chaykovsky reported the first preparation of the dimethylsulfinyl carbanion in dimethyl sulfoxide (DMSO) solution [2]. A recent NMR study [3] suggests that the dimethylsulfinyl carbanion $\mathrm{CH}_{2} \mathrm{~S}(\mathrm{O}) \mathrm{CH}_{3}^{-}$is actually a tridentate nucleophile, i.e., it can behave as an $\mathrm{O}-$, S-, or C-nucleophile in organic reactions. Because of this synthetic relevance, the study of the intrinsic chemistry of these carbanions in the gas phase is receiving increased attention. DePuy et al. [4] found that nitromethyl anion $\mathrm{CH}_{2} \mathrm{NO}_{2}^{-}$fails to undergo $\mathrm{H} / \mathrm{D}$ exchange with deuterated methanol $\mathrm{CH}_{3} \mathrm{OD}$ but exchanges both hydrogens with $\mathrm{CF}_{3} \mathrm{CH}_{2} \mathrm{OD}$. Bartmess and coworkers

Published online October 24, 2005

Address reprint requests to Dr. R. G. Cooks, Department of Chemistry, Purdue University, 560 Oval Drive, West Lafayette, IN 47907-1393, USA. E-mail: cooks@purdue.edu.

* Also at Institute of Chemistry, State University of Campinas, UNICAMP Campinas SP, Brazil. E-mail: eberlin@iqm.unicamp.br
[5] observed that Claisen condensation products are formed in the reactions of $\mathrm{CH}_{2} \mathrm{NO}_{2}^{-}, \mathrm{CH}_{2} \mathrm{CN}^{-}$, and $\mathrm{CH}_{2} \mathrm{~S}(\mathrm{O}) \mathrm{CH}_{3}^{-}$with $\mathrm{HCO}_{2} \mathrm{CH}=\mathrm{CH}_{2}$ performed in an ion cyclotron resonance spectrometer (ICR). Grabowski and Zhang [6] examined the anion/molecule reactions of $\mathrm{CH}_{2} \mathrm{NO}_{2}^{-}$and $\mathrm{CH}_{2} \mathrm{CN}^{-}$with dimethyl disulfide. While nitromethyl carbanion reacted slowly but completely to give $\mathrm{CH}_{3} \mathrm{SCHNO}_{2}^{-}$as the sole primary product ion, cyanomethyl carbanion also underwent substitution at sulfur. However, the reactivity of these carbanions towards halogenated compounds, especially haloalkanes, has seen little study although the gasphase ion/molecule reactions with neutral halomethanes have been extensively investigated by Grabowski et al. [7], Knighton and Grimsrud [8], and Nibbering and coworkers $[9,10]$. Products arising from dissociative electron-transfer (DET), $\mathrm{S}_{\mathrm{N}} 2$ nucleophilic substitution, and proton abstraction reactions were observed.

In the condensed phase, the tetrahalogenated methanes such as $\mathrm{CCl}_{4}$ are fairly unreactive toward the usual nucleophilic agents and are often used as inert media in organic synthesis. However, they are especially labile toward the halogenophilic attack [11]. For instance, the conversion of alcohols into the corresponding alkylchlorides using $\mathrm{CCl}_{4}$ and $\mathrm{PPh}_{3}$ proceeds with chlorine cation transfer from $\mathrm{CCl}_{4}$ to $\mathrm{PPh}_{3}$ to form an intermediate $\left[\mathrm{Ph}_{3} \mathrm{PCl}\right]^{+} \mathrm{CCl}_{3}^{-}$[12]. Examination of the reaction of the free carbanions as nucleophiles with haloalkanes is therefore desirable.

Hydrogen/chlorine exchange is quite a general phenomenon in condensed-phase reactions and it is of 

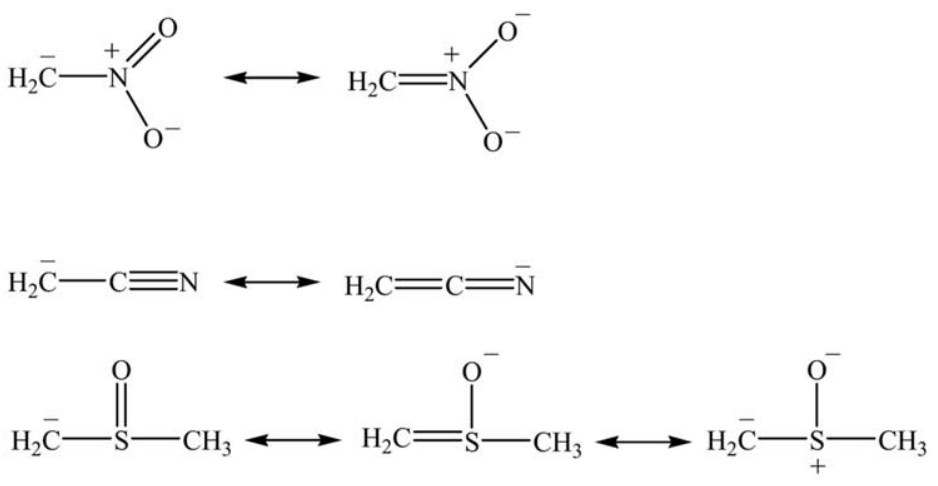

Scheme 1

interest because it can offer a convenient means to prepare chlorination products. The most common hydrogen/chlorine exchange reaction is the photocatalyzed chlorination of hydrocarbons with $\mathrm{Cl}_{2}$ gas, which involves $\mathrm{Cl}$ radical intermediates. However, nonradical hydrogen/chlorine exchange reactions of both negative and positive chlorine have been also reported. Exchange of halogen and hydrogen between organic halides such as $t$-butyl chloride and hydrocarbons such as 2-methlybutane under $\mathrm{AlCl}_{3}$ catalysis was observed by Bartlett et al. [13]. The reaction was proposed to begin with the formation of an ionic intermediate $\mathrm{Me}_{3} \mathrm{C}^{+} \cdot \mathrm{AlCl}_{4}^{-}$, subsequent deprotonation of 2-methylbutane by $\mathrm{Me}_{3} \mathrm{C}^{+}$and then chloride $\mathrm{Cl}^{-}$transfer from $\mathrm{AlCl}_{4}^{-}$to the depronated 2-methylisobutane (Scheme 2). A similar hydrogen/chlorine exchange reaction between bicyclo [2,2,1]heptane and t-butyl chloride catalyzed by $\mathrm{AlCl}_{3}$ was later reported by Schmerling, who found the chlorination product to be 2-chlorobicycle $[2,2,1]$ heptane rather than 1-chlorobicycle $[2,2,1]$ heptane because the tertiary carbonium ion is not stable (Scheme 3, eq 1) [14]. This kind of reaction has been extended to boron compounds. Zakharkin observed that refluxing carborane in $\mathrm{CCl}_{4}$ or $\mathrm{CHCl}_{3}$ under $\mathrm{AlCl}_{3}$ catalysis gave mono-, di-, and trichlorocarboranes with chlorine replacing hydrogen atoms in the $\mathrm{B}_{10} \mathrm{H}_{10}$ moiety [15]. Kerrigan reported that the exchange of hydrogen and chlorine atoms occurs in the course of the interaction of boron trichloride and diborane to yield monochlorodiborane and dichloroborane (Scheme 3 , eq 2) [16]. Kondo developed a method for detection of

$\mathrm{Me}_{3} \mathrm{CCl}+\mathrm{AlCl}_{3} \rightleftharpoons \mathrm{Me}_{3} \mathrm{C}^{+} \cdot \mathrm{AlCl}_{4}{ }^{-}$

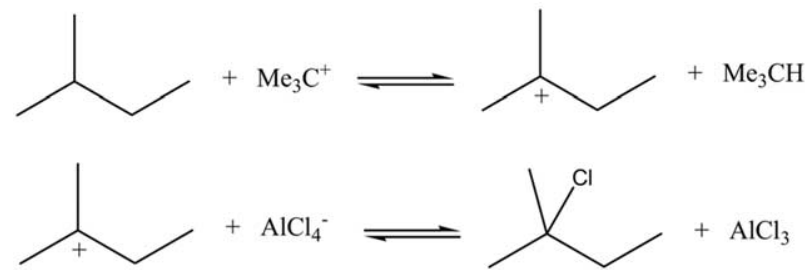

Scheme 2 intramolecularly hydrogen-bonded peptide $\mathrm{NH}$ groups based on a hydrogen/chlorine exchange reaction with reagents of positive chlorine, $t-\mathrm{BuOCl}$ or chlorine, and proposed a positive chlorine transfer mechanism [17].

The present study investigates the ion/molecule reactions of three typical carbanions $\mathrm{CH}_{2} \mathrm{NO}_{2}^{-}$, $\mathrm{CH}_{2} \mathrm{CN}^{-}$, and $\mathrm{CH}_{2} \mathrm{~S}(\mathrm{O}) \mathrm{CH}_{3}^{-}$with the chloromethanes $\mathrm{CH}_{2} \mathrm{Cl}_{2}, \mathrm{CHCl}_{3}$, and $\mathrm{CCl}_{4}$, and reports on a novel gas-phase hydrogen/chlorine exchange reaction between nitromethyl anion $\mathrm{CH}_{2} \mathrm{NO}_{2}^{-}$and tetrachloromethane $\mathrm{CCl}_{4}$. The reaction mechanism probably involves nucleophilic attack of $\mathrm{CH}_{2} \mathrm{NO}_{2}^{-}$to a chlorine of $\mathrm{CCl}_{4}$ followed by proton transfer within the resulting complex $\left[\mathrm{CH}_{2} \mathrm{ClNO}_{2}+\mathrm{CCl}_{3}^{-}\right]$to form $\mathrm{CHClNO}_{2}^{-}$and $\mathrm{CHCl}_{3}$.

\section{Experimental}

Ion/molecule reactions were carried out on a Finnigan TSQ-70 triple quadrupole mass spectrometer (Thermo Finnigan, San Jose, $\mathrm{CA}$ ). The mass-selected reactant ions $\mathrm{CH}_{2} \mathrm{NO}_{2}^{-}, \mathrm{CH}_{2} \mathrm{CN}^{-}$, and $\mathrm{CH}_{2} \mathrm{~S}(\mathrm{O}) \mathrm{CH}_{3}^{-}$were generated by negative chemical ionization $(\mathrm{CI})$ of the neutrals $\mathrm{CH}_{3} \mathrm{NO}_{2}, \mathrm{CH}_{3} \mathrm{CN}$, and $\mathrm{CH}_{3} \mathrm{~S}(\mathrm{O}) \mathrm{CH}_{3}$, respectively, using isobutane as the buffer gas. Ion/molecule reactions were performed by mass selection of the precursor ion of interest in Q1, reaction with neutral reagent in Q2, and product ion mass analysis using Q3 to monitor product ions. The collision energy, given as the voltage difference between the ion source and the collision quadrupole, was nominally $0 \mathrm{eV}$ for ion/molecule reactions and $10 \mathrm{eV}$ for collision-induced dissociation (CID). All compounds were commercially available and used without further purification.

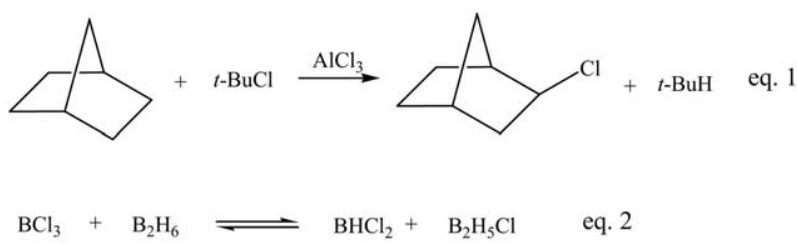

Scheme 3 
Table 1. Major ionic products of the ion/molecule reactions between carbanions and chloromethanes

\begin{tabular}{|c|c|c|c|c|c|c|}
\hline \multirow{2}{*}{\multicolumn{2}{|c|}{ Reagents }} & \multicolumn{5}{|c|}{ Products $(\mathrm{m} / \mathrm{z})$} \\
\hline & & \multirow[b]{2}{*}{$\mathrm{H} / \mathrm{Cl}$ exchange } & \multirow[b]{2}{*}{ Chlorine abstraction } & \multirow[b]{2}{*}{$\begin{array}{c}\text { Proton } \\
\text { abstraction }\end{array}$} & \multirow{2}{*}{$\begin{array}{c}\text { Nucleophilic } \\
\text { substitution } \\
\left(\mathrm{S}_{\mathrm{N}} 2\right)\end{array}$} & \multirow[b]{2}{*}{$\begin{array}{l}\text { Other } \\
\text { ions }\end{array}$} \\
\hline Ions $(\mathrm{m} / \mathrm{z})$ & Neutral & & & & & \\
\hline \multirow[t]{3}{*}{$\mathrm{CH}_{2} \mathrm{NO}_{2}^{-}(60)$} & $\mathrm{CH}_{2} \mathrm{Cl}_{2}$ & $-^{a}$ & - & - & - & - \\
\hline & $\mathrm{CHCl}_{3}$ & - & - & $\mathrm{CCl}_{3}^{-}(117)$ & - & 42,46 \\
\hline & $\mathrm{CCl}_{4}$ & $\mathrm{CHCINO}_{2}^{-}(94)$ & $\mathrm{CCl}_{3}^{-}(117)$ & - & - & $42^{\mathrm{b}}$ \\
\hline \multirow[t]{3}{*}{$\mathrm{CH}_{2} \mathrm{CN}^{-}(40)$} & $\mathrm{CH}_{2} \mathrm{Cl}_{2}$ & - & - & $\mathrm{CHCl}_{2}^{-}$(83) & $\mathrm{Cl}^{-}(35)$ & - \\
\hline & $\mathrm{CHCl}_{3}$ & - & - & $\mathrm{CCl}_{3}^{-}(117)$ & - & - \\
\hline & $\mathrm{CCl}_{4}$ & $\mathrm{CHClCN}^{-}(74)^{\mathrm{b}}$ & $\mathrm{CCl}_{3}^{-}(117)$ & - & $\mathrm{Cl}^{-}(35)$ & - \\
\hline \multirow[t]{3}{*}{$\mathrm{CH}_{2} \mathrm{SOCH}_{3}^{-}(77)$} & $\mathrm{CH}_{2} \mathrm{Cl}_{2}$ & - & - & $\mathrm{CHCl}_{2}^{-}(83)$ & $\mathrm{Cl}^{-}(35)$ & 49,61 \\
\hline & $\mathrm{CHCl}_{3}$ & - & - & $\mathrm{CCl}_{3}^{-}(117)$ & - & - \\
\hline & $\mathrm{CCl}_{4}$ & $\mathrm{CHCIS}(\mathrm{O}) \mathrm{CH}_{3}^{-}(111)^{\mathrm{b}}$ & $\mathrm{CCl}_{3}^{-}(117)$ & - & $\mathrm{Cl}^{-}(35)^{\mathrm{b}}$ & 49,61 \\
\hline
\end{tabular}

a Not observed.

bVery weak.

Optimized geometries and energies of idealized conformations were obtained by density functional theory (DFT) calculations using the B3LYP/6-311G $(\mathrm{d}, \mathrm{p})$ basis set as implemented in Gaussian 2003 program [18]. The zero-point vibrational energies were scaled by a factor of $0.9806[19,20]$ and incorporated into the final total energy calculations.

\section{Results and Discussion}

Table 1 summarizes the results of the reactions of the three carbanions with the chloromethanes $\mathrm{CH}_{2} \mathrm{Cl}_{2}$, $\mathrm{CHCl}_{3}$, and $\mathrm{CCl}_{4}$. Figure 1a displays the product ion mass spectrum for reactions of nitromethyl anion $\mathrm{CH}_{2} \mathrm{NO}_{2}^{-}$of $m / z 60$ with $\mathrm{CCl}_{4}$. The main product ion is

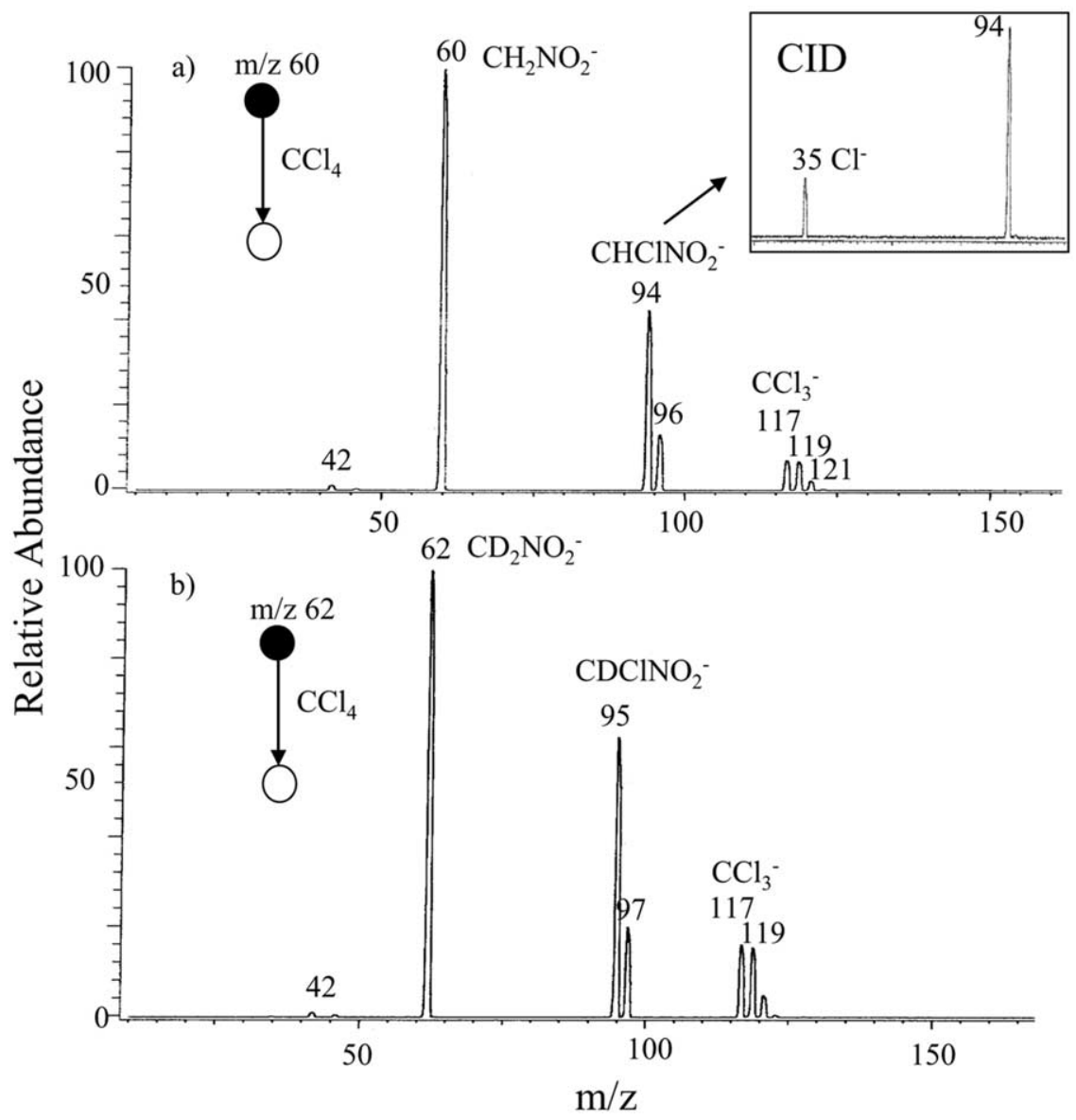

Figure 1. Product ion mass spectra for ion/molecule reactions of: (a) $\mathrm{CH}_{2} \mathrm{NO}_{2}^{-}$of $\mathrm{m} / z$ 60 and (b) $\mathrm{CD}_{2} \mathrm{NO}_{2}^{-}$of $\mathrm{m} / \mathrm{z} 62$ with $\mathrm{CCl}_{4}$ at nominally $0 \mathrm{eV}$ collision energy. 
Table 2. B3LYP/6-311G $(\mathrm{d}, \mathrm{p})$ calculated energies for molecules and cations in the hydrogen/chlorine exchange reaction

\begin{tabular}{|c|c|c|c|c|}
\hline Species & $\begin{array}{c}\text { Energy } \\
\left(\text { Hartrees }^{\mathrm{a}}\right)\end{array}$ & $\begin{array}{l}\text { Zero-point energy } \\
\text { (Hatrees) }\end{array}$ & $\begin{array}{l}\text { Corrected energy } \\
\text { (Hartress) }\end{array}$ & $\Delta \mathrm{E}(\mathrm{kcal} / \mathrm{mol})$ \\
\hline $\mathrm{CH}_{2} \mathrm{NO}_{2}^{-}(1)$ & -244.4874087 & 0.035501 & -244.4525964 & $-{ }^{c}$ \\
\hline $\mathrm{CCl}_{4}(2)$ & -1878.9771155 & 0.009216 & -1878.968078 & - \\
\hline $\mathrm{HCCl}_{3}(3)$ & -1419.3755056 & 0.019787 & -1419.356102 & - \\
\hline $\mathrm{CHCINO}_{2}^{-}(4)$ & -704.1206603 & 0.027217 & -704.0939713 & - \\
\hline $\mathrm{H}^{\bullet}(5)$ & -0.5021559 & 0.000000 & -0.5021559 & - \\
\hline $\mathrm{CCl}_{3}^{\bullet}(6)$ & -1418.7166789 & 0.007007 & -1418.709808 & - \\
\hline $\mathrm{CCl}_{3}^{-}(7)$ & -1418.7973556 & 0.004786 & -1418.792662 & - \\
\hline $\mathrm{CH}_{2} \mathrm{CINO}_{2}$ (8) & -704.6910491 & 0.041223 & -704.6506258 & - \\
\hline$\left[\mathrm{CH}_{2} \mathrm{NO}_{2}^{-}+\mathrm{CCl}_{4}\right](9)$ & -2123.4913040 & 0.045643 & -2123.446546 & - \\
\hline$\left[\mathrm{CH}_{2} \mathrm{CINO}_{2}+\mathrm{CCl}_{3}^{-}\right](10)$ & -2123.5146422 & 0.046468 & -2123.469076 & - \\
\hline$\left[\mathrm{CHCINO}{ }_{2}^{-}+\mathrm{CHCl}_{3}\right](11)$ & -2123.5183855 & 0.047170 & -2123.472131 & - \\
\hline$\left[\mathrm{CH}_{2} \mathrm{CINO}_{2}^{-\bullet}+\mathrm{CCl}_{3}^{\bullet}\right](12)$ & -2123.4364868 & 0.044162 & -2123.393182 & - \\
\hline$(3+4)-(1+2)$ & - & - & - & -18 \\
\hline$(4+5+6)-(1+2)$ & - & - & - & +72 \\
\hline$(7+8)-(1+2)$ & - & - & - & -14 \\
\hline (9) $-(1+2)$ & - & - & - & -16 \\
\hline$(10)-(1+2)$ & - & - & - & -30 \\
\hline$(11)-(1+2)$ & - & - & - & -32 \\
\hline$(12)-(1+2)$ & - & - & - & +17 \\
\hline
\end{tabular}

a1 Hartree $=627.51 \mathrm{kcal} / \mathrm{mol}$

${ }^{\mathrm{b}}$ Corrected $\mathrm{E}=\mathrm{E}+0.9806 \times$ Zero-point $\mathrm{E}$

'Not applied

that of $\mathrm{m} / \mathrm{z} 94$ with an isotopologue of $\mathrm{m} / \mathrm{z} 96$ of one third the abundance corresponding to $\mathrm{CHClNO}_{2}^{-}$. The assignment of this ion was confirmed by observing the ion $\mathrm{CDClNO}_{2}^{-}$of $\mathrm{m} / \mathrm{z} 95$ in the spectrum shown in Figure $1 \mathrm{~b}$ for which the isotopologue carbanion $\mathrm{CD}_{2} \mathrm{NO}_{2}^{-}$of $m / z 62$ was used. The fragmentation behavior of the product ion $\mathrm{CH}^{35} \mathrm{ClNO}_{2}^{-}$of $\mathrm{m} / \mathrm{z} 94$ upon collision with argon under $10 \mathrm{eV}$ collision energy was used for its further characterization. This process yields just one fragment ion, $\mathrm{Cl}^{-}$of $\mathrm{m} / \mathrm{z} 35$, see the inset in Figure 1a, possibly by loss of the neutral carbene: $\mathrm{CHNO}_{2}$ and in a good agreement with the formation of $\mathrm{Br}^{-}$of $m / z 79$ from the CID of $\mathrm{CH}^{79} \mathrm{BrNO}_{2}^{-}$of $\mathrm{m} / \mathrm{z}$ 138 generated by negative chemical ionization of $\mathrm{CH}_{2} \mathrm{BrNO}_{2}$ using isobutane as the buffer gas.

To form $\mathrm{CHClNO}_{2}^{-}$from the reaction of $\mathrm{CH}_{2} \mathrm{NO}_{2}^{-}$ and $\mathrm{CCl}_{4}$, the neutral product could be either a neutral molecule of chloroform $\mathrm{CHCl}_{3}$ or two radicals: $\mathrm{H}$. plus $\cdot \mathrm{CCl}_{3}$. The latter possibility can be excluded since this pathway is predicted to be endothermic by $72 \mathrm{kcal} \mathrm{mol}^{-1}$ by DFT calculations at the B3LYP/6-311G(d,p) level. Loss of neutral chloroform is, however, favorable in energy, that is, it is exothermic by $18 \mathrm{kcal} \mathrm{mol}^{-1}$. Table 2 summarizes the calculated energies of the species in the reaction. It can be seen that the formal hydrogen/chlorine exchange between $\mathrm{CH}_{2} \mathrm{NO}_{2}^{-}$and $\mathrm{CCl}_{4}$ occurs, as shown in the net reaction (eq 3 ). The ions of $m / z 117,119$, and 121 in Figure 1a are attributable to the different isotopologues of $\mathrm{CCl}_{3}^{-}$, and another ion of $m / z 42$ likely arises from the dissociation of the reactant ion $\mathrm{CH}_{2} \mathrm{NO}_{2}^{-}$by the loss of $\mathrm{H}_{2} \mathrm{O}$.

$$
\mathrm{CH}_{2} \mathrm{NO}_{2}^{-}+\mathrm{CCl}_{4} \rightarrow \mathrm{CHClNO}_{2}^{-}+\mathrm{CHCl}_{3}
$$

Scheme 4 proposes a mechanism for this novel hydrogen/chlorine exchange reaction. $\mathrm{CH}_{2} \mathrm{NO}_{2}^{-}$is initially attracted to neutral $\mathrm{CCl}_{4}$ to form a transient complex $\left[\mathrm{CH}_{2} \mathrm{NO}_{2}^{-}+\mathrm{CCl}_{4}\right]$ and this complexation releases $16 \mathrm{kcal} \mathrm{mol}^{-1}$ (Table 2). A subsequent intermolecular transfer of $\mathrm{Cl}^{+}$from $\mathrm{CCl}_{4}$ to $\mathrm{CH}_{2} \mathrm{NO}_{2}^{-}$(i.e., nucleophilic attack on chlorine of $\mathrm{CCl}_{4}$ by $\mathrm{CH}_{2} \mathrm{NO}_{2}^{-}$) occurs to produce a second complex $\left[\mathrm{CH}_{2} \mathrm{ClNO}_{2}+\right.$ $\left.\mathrm{CCl}_{3}^{-}\right]$and this step is also thermodynamically favorable, that is, it is exothermic by as much as $30 \mathrm{kcal}$ $\mathrm{mol}^{-1}$. The possibility of $\mathrm{Cl}^{-}$transfer in the initial complex can be excluded on Coulombic grounds. Another alternative pathway of chlorine radical transfer is also unlikely since the calculations show that the formation of the complex $\left[\mathrm{CH}_{2} \mathrm{ClNO}_{2}^{-\cdot}+\mathrm{CCl}_{3}\right]$ is endothermic by $+17 \mathrm{kcal} \mathrm{mol}^{-1}$. The remaining possibility, $\mathrm{Cl}^{+}$transfer, is considered likely. In the literature, intermolecular chlorine cation transfer was also previously proposed to occur in the condensed phase from a $\mathrm{N}$-chloroanilinium ion to an aniline [21] and from $\mathrm{CCl}_{4}$ to $\mathrm{PPh}_{3}$ [12] as mentioned earlier. In the case being discussed, a subsequent intermolecular proton transfer takes place within the second complex $\left[\mathrm{CH}_{2} \mathrm{ClNO}_{2}+\right.$ $\left.\mathrm{CCl}_{3}^{-}\right]$to form a third complex $\left[\mathrm{CHClNO}_{2}^{-}+\mathrm{CHCl}_{3}\right]$ and the hydrogen/chlorine exchange products, $\mathrm{CHClNO}_{2}^{-}$and $\mathrm{CHCl}_{3}$, thus arise from the dissociation of the third complex. The exothermicity of the formation of the third complex $\left[\mathrm{CHClNO}_{2}^{-}+\mathrm{CHCl}_{3}\right]$ from $\mathrm{CH}_{2} \mathrm{NO}_{2}^{-}$and $\mathrm{CCl}_{4}$ is $32 \mathrm{kcal} \mathrm{mol}^{-1}$. Overall, in this reaction, the exchange of chlorine and hydrogen is stepwise and occurs via three ion-neutral intermediate complexes, in a mechanism very similar to that reported for the hydrogen/deuterium exchange in the gas phase [22]. Interestingly, no further $\mathrm{H} / \mathrm{Cl}$ exchange occurs to 


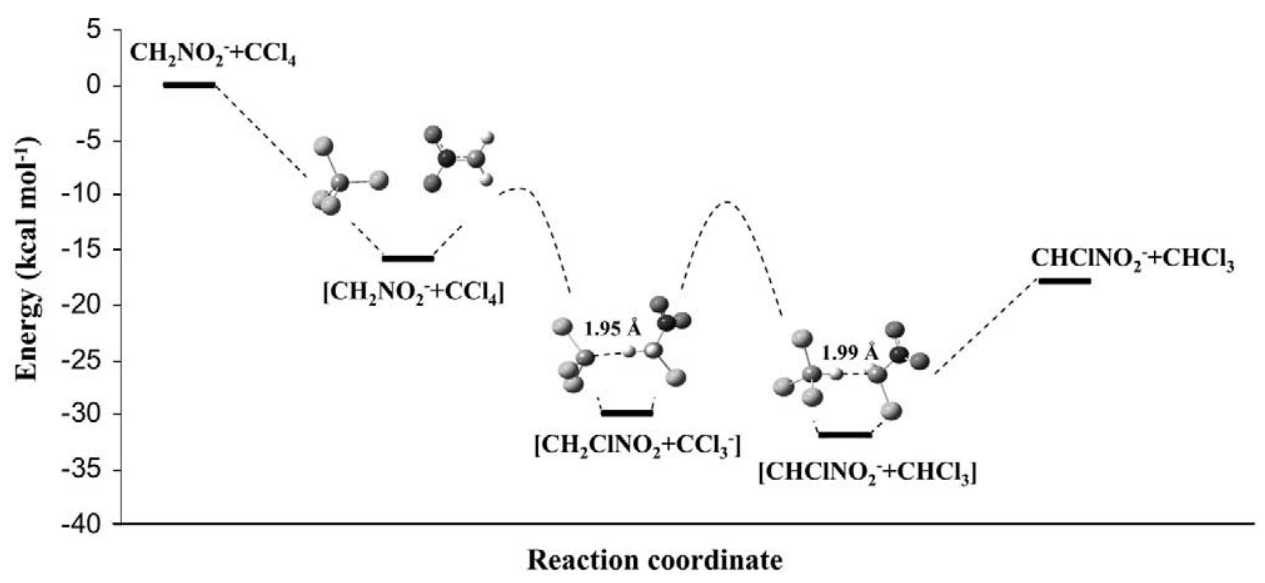

Scheme 4

form $\mathrm{CCl}_{2} \mathrm{NO}_{2}^{-}$, probably because with one more electron-withdrawing $\mathrm{Cl}$ atom, $\mathrm{CHClNO}_{2}^{-}$is less nucleophilic than $\mathrm{CH}_{2} \mathrm{NO}_{2}^{-}$. Note that as Scheme 4 shows, energy barriers might exist in the conversion from the initial complex to the second complex and from the second to the third complex. The latter two complexes are stabilized by hydrogen bonding (Scheme 4).

Another product ion, $\mathrm{CCl}_{3}^{-}$of $\mathrm{m} / z \mathrm{117}$, is also observed in the spectrum of Figure $1 \mathrm{a}$, and this ion is probably formed by direct attack on a chlorine atom of $\mathrm{CCl}_{4}$ by $\mathrm{CH}_{2} \mathrm{NO}_{2}^{-}$. The exothermicity for the formation of $\mathrm{CCl}_{3}^{-}$ from reactants $\mathrm{CH}_{2} \mathrm{NO}_{2}^{-}$and $\mathrm{CCl}_{4}$ is $-14 \mathrm{kcal} \mathrm{mol}^{-1}$. Direct nucleophilic attack on a halogen atom in an organic compound by an anion has been described for both condensed- [11, 23] and gas-phase reactions [24]. For example, $\alpha$-chlorination to the carbonyl compounds effected by $\mathrm{CCl}_{4}$ in basic media involves the nucleophilic attack on a $\mathrm{Cl}$ atom of the $\mathrm{CCl}_{4}$ by the intermediate carbonyl anion and the reactivity increases with decreased delocalization of its negative charge [23]. Nibbering et al. reported that nucleophilic attack on a chlorine atom is the exclusive reaction of the allyl anion with $\mathrm{CF}_{3} \mathrm{Cl}$ in the gas phase [24].

As seen from the discussion above, the carbanion $\mathrm{CH}_{2} \mathrm{NO}_{2}^{-}$is further functionalized via a simple reaction with $\mathrm{CCl}_{4}$. Potentially, this reaction could find synthetic applications in solution since the $\mathrm{CH}_{2} \mathrm{ClNO}_{2}^{-}$may subsequently undergo a Henry/nitroaldol reaction. In the gas-phase reaction between $\mathrm{OH}^{-}$and $\mathrm{CCl}_{4}$ to form $\mathrm{Cl}^{-}$ and $\mathrm{CCl}_{3}^{-}$performed in a FT-ICR mass spectrometer, Nibbering and coworkers observed hydrogen/chlorine exchange products of $\mathrm{OCl}^{-}$and $\mathrm{CHCl}_{3}$ as the minor products [25].

We also examined the reactions of carbanions $\mathrm{CH}_{2} \mathrm{CN}^{-}$of $m / z 40$ and $\mathrm{CH}_{2} \mathrm{~S}(\mathrm{O}) \mathrm{CH}_{3}^{-}$of $\mathrm{m} / z 77$ with $\mathrm{CCl}_{4}$. To our surprise, unlike $\mathrm{CH}_{2} \mathrm{NO}_{2}^{-}$, both $\mathrm{CH}_{2} \mathrm{CN}^{-}$ and $\mathrm{CH}_{2} \mathrm{~S}(\mathrm{O}) \mathrm{CH}_{3}^{-}$form fairly weak hydrogen/chlorine exchange products $\mathrm{CHClCN}^{-}$of $\mathrm{m} / z 74$ and $\mathrm{CHClS}^{-}$ (O) $\mathrm{CH}_{3}^{-}$of $\mathrm{m} / z 111$ with $\mathrm{CCl}_{4}$. Instead, $\mathrm{Cl}^{-}$and $\mathrm{CCl}_{3}^{-}$ were observed in both cases. The formation of $\mathrm{Cl}^{-}$ could be due to either dissociative electron-transfer since cyanomethyl radical has a lower electron affinity (1.5 eV) [26] than $\mathrm{CCl}_{4}(2.0 \mathrm{eV})$ [27] or from the nucleophilic displacement of $\mathrm{CCl}_{4}\left(\mathrm{~S}_{\mathrm{N}} 2\right.$ mechanism) because $\mathrm{CH}_{2} \mathrm{CN}^{-}$is also a good nucleophile towards formation of $\mathrm{C}-\mathrm{C}$ bonds. However $\mathrm{CCl}_{4}^{-}$, a common intermediate in typical dissociative electron of $\mathrm{CCl}_{4}$ transfer [8], was not observed, indicating that the nucleophilic substitution $S_{N} 2$ reaction might indeed be responsible for the formation of $\mathrm{Cl}^{-}$. Due to the presence of competitive nucleophilic substitutions, the hydrogen/chlorine exchange reactions of $\mathrm{CH}_{2} \mathrm{CN}^{-}$and $\mathrm{CH}_{2} \mathrm{~S}(\mathrm{O}) \mathrm{CH}_{3}^{-}$with $\mathrm{CCl}_{4}$ are prevented. This can be rationalized by the different electron-withdrawing effect of the substitution groups of the three carbanions. Because nitro group has a larger electron-withdrawing effect than cyano and sulfinyl groups [28], the nucleophilicity of $\mathrm{CH}_{2} \mathrm{CN}^{-}$and $\mathrm{CH}_{2} \mathrm{~S}(\mathrm{O}) \mathrm{CH}_{3}^{-}$toward $\mathrm{CCl}_{4}$ is therefore higher than that of $\mathrm{CH}_{2} \mathrm{NO}_{2}^{-}$. This rationale is also supported by experimental evidence that another competitive reaction with the hydrogen/chlorine exchange, the direct nucleophilic chlorine attack of $\mathrm{CCl}_{4}$ by $\mathrm{CH}_{2} \mathrm{CN}^{-}$or $\mathrm{CH}_{2} \mathrm{~S}(\mathrm{O}) \mathrm{CH}_{3}^{-}$, forms an abundance of $\mathrm{CCl}_{3}^{-}$signals as the main product in the reaction of $\mathrm{CH}_{2} \mathrm{CN}^{-}$or $\mathrm{CH}_{2} \mathrm{~S}(\mathrm{O}) \mathrm{CH}_{3}^{-}$with $\mathrm{CCl}_{4}$, analogous with the observation of intermediate phenylchloroacetonitrile $\mathrm{PhCHClCN}$ in the chlorination of phenylacetonitrile $\mathrm{PhCH}_{2} \mathrm{CN}$ by $\mathrm{CCl}_{4}$ in the presence of sodium hydroxide [29]. The distinct reactivity toward $\mathrm{CCl}_{4}$ can be used to differentiate $\mathrm{CH}_{2} \mathrm{NO}_{2}^{-}$from $\mathrm{CH}_{2} \mathrm{CN}^{-}$and $\mathrm{CH}_{2} \mathrm{~S}(\mathrm{O}) \mathrm{CH}_{3}^{-}$.

All three carbanions have similar reactivity towards chloroform $\left(\mathrm{CHCl}_{3}\right)$ and form exclusively $\mathrm{CCl}_{3}^{-}$of $\mathrm{m} / \mathrm{z} 117$ by proton abstraction, as Figure 2 exemplifies for the reaction of $\mathrm{CH}_{2} \mathrm{NO}_{2}^{-}$and $\mathrm{CHCl}_{3}$. This reactivity is analogous with the reaction of $\mathrm{O}^{-\cdot}$ with $\mathrm{CHCl}_{3}[9,10]$. However, when $\mathrm{CH}_{2} \mathrm{Cl}_{2}$ is chosen as the neutral reactant, both proton abstraction and nucleophilic displacement are observed to form $\mathrm{CHCl}_{2}^{-}, m / z$ 83, and $\mathrm{Cl}^{-}, \mathrm{m} / \mathrm{z}$ 35 , in the reaction with $\mathrm{CH}_{2} \mathrm{CN}^{-}$and $\mathrm{CH}_{2} \mathrm{~S}(\mathrm{O}) \mathrm{CH}_{3}^{-}$ while $\mathrm{CH}_{2} \mathrm{NO}_{2}^{-}$is inert. Again, these results suggest that the nucleophilicity of $\mathrm{CH}_{2} \mathrm{NO}_{2}^{-}$is the lowest among the three carbanions. 


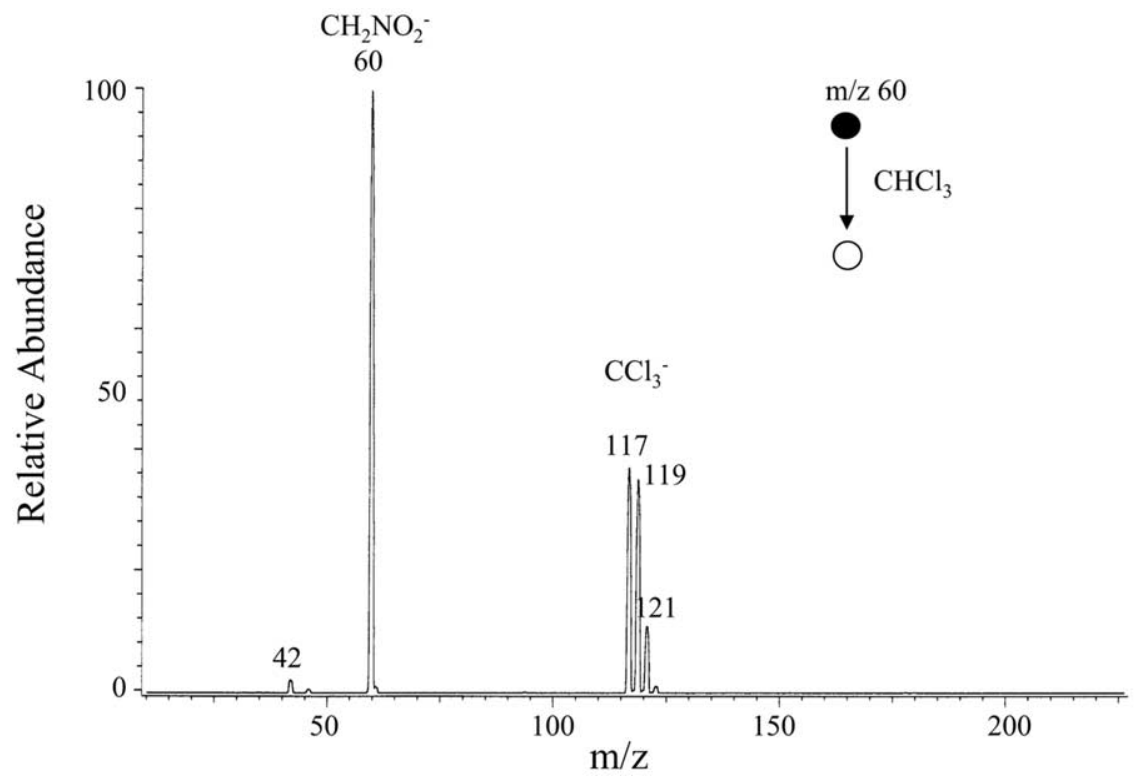

Figure 2. Product ion mass spectrum for ion/molecule reaction of $\mathrm{CH}_{2} \mathrm{NO}_{2}^{-}$of $m / z 60$ with $\mathrm{CHCl}_{3}$ at nominally $0 \mathrm{eV}$ collision energy

\section{Conclusions}

Investigation on the gas-phase ion/molecule reactions of three typical carbanions with chloromethanes shows that $\mathrm{CH}_{2} \mathrm{NO}_{2}^{-}$reacts efficiently via a novel hydrogen/ chlorine exchange pathway with $\mathrm{CCl}_{4}$ to yield $\mathrm{CHClNO}_{2}^{-}$and $\mathrm{CHCl}_{3}$ likely via a complex in which chlorine cation transfer and subsequent proton transfer occurs. By contrast, $\mathrm{CH}_{2} \mathrm{CN}^{-}$and $\mathrm{CH}_{2} \mathrm{~S}(\mathrm{O}) \mathrm{CH}_{3}^{-}$have much lower hydrogen/chlorine exchange reactivities with $\mathrm{CCl}_{4}$ due to the presence of competitive nucleophilic attack on both carbon and chlorine of $\mathrm{CCl}_{4}$. The conversion of $\mathrm{CH}_{2} \mathrm{NO}_{2}^{-}$into $\mathrm{CHClNO}_{2}^{-}$via this simple $\mathrm{H} / \mathrm{Cl}$ exchange reaction might be worthy of extension to the investigation of carbon-carbon bond formation reaction by further reacting $\mathrm{CHClNO}_{2}^{-}$with electrophiles such as aldehydes. All three carbanions react with $\mathrm{CHCl}_{3}$ via proton abstraction. For the reactions of $\mathrm{CH}_{2} \mathrm{CN}^{-}$and $\mathrm{CH}_{2} \mathrm{~S}(\mathrm{O}) \mathrm{CH}_{3}^{-}$with $\mathrm{CH}_{2} \mathrm{Cl}_{2}$, both proton abstraction and nucleophilic displacement products are predominant owing to the high nucleophilicity of these carbanions.

\section{Acknowledgments}

The authors acknowledge support from the National Science Foundation (CHE04-12,782), the U.S. Department of Energy, Office of Basic Energy Sciences, and the Brazilian research foundations $\mathrm{CNPq}$ and FAPESP.

\section{References}

1. Palomo, C.; Oiarbide, M.; Mielgo, A. Unveiling Reliable Catalysts for the Asymmetric Nitroaldol (Henry) Reaction. Angew. Chem. Int. Ed. 2004, 43, 5442-5444.

2. Corey, E. J.; Chaykovsky, M. J. Methylsulfinylcarbanion. J. Am. Chem. Soc. 1962, 84, 866-867.
3. Buncel, E.; Park, K.-T.; Dust, J. M.; Manderville, R. A. Concerning the Denticity of the Dimethylsulfinyl Anion in Meisenheimer Complexation. J. Am. Chem. Soc. 2003, 125, $5388-5392$.

4. Stewart, J. H.; Shapiro, R. H.; Depuy, C. H.; Bierbaum, V. M. Hydrogen-Deuterium Exchange Reactions of Carbanions with Water- $\mathrm{d}_{2}$ in the Gas Phase. J. Am. Chem. Soc. 1977, 99, 7650-7653.

5. Bartmess, J. E.; Hays, R. J.; Caldwell, G. The Addition of Carbanions to the Carbonyl Group in the Gas Phase. J. Am. Chem. Soc. 1982, 103, 1338-1344.

6. Grabowski, J. J.; Zhang, L. Dimethyl Disulfide: AnionMolecule Reactions in the Gas Phase at 300 K. J. Am. Chem. Soc. 1989, 111, 1193-1203.

7. Rinden, E.; Maricq, M. M.; Grabowski, J. J. Gas-Phase IonMolecule Reactions of the Nitric Oxide Anion. J. Am. Chem. Soc. 1989, 111, 1203-1210.

8. Knighton, W. B.; Grimsrud, E. P. Gas-Phase Electron-Transfer Reactions Between Selected Molecular Anions and Halogenated Methanes. J. Am. Chem. Soc. 1992, 114, 2336-2342.

9. Staneke, P. O.; Groothuis, G.; Ingemann, S.; Nibbering, N. M. M. Competing Electron Transfer, Proton Abstraction, and Nucleophilic Substitutions in Gas-Phase Reactions of (Radical) Anions with Chloro- and Bromomethanes. J. Phys. Org. Chem. 1996, 9, 471-486.

10. Staneke, P. O.; Kauw, J.; Born, M.; Ingemann, S.; Nibbering, N. M. M. Low Pressure Gas-Phase Reactions of the Atomic Oxygen Radical Anion with Halomethanes Studied Using Fourier Transform Ion Cyclotron Resonance. Rapid Commun. Mass Spectrom. 1997, 11, 124-132.

11. Zefirov, N. S.; Marhon'kov, D. I. X-Philic Reactions. Chem. Rev. $1982,82,615-624$.

12. Slagle, J. D.; Huang, T. T.-S.; Franzus, B. Mechanism of Triphenylphosphine-Tetrachloromethane-Alcohol Reaction: Pericyclic or Clustered Ion Pairs? J. Org. Chem. 1981, 46, 3526-3530.

13. Bartlett, P. D.; Condon, F. E.; Schneid, A. Exchanges of Halogen and Hydrogen Between Organic Halides and Isoparaffins in the Presence of Aluminum Halides. J. Am. Chem. Soc. 1944, 66, 1531-1539. 
14. Schmerling, L. The Exchange of Hydrogen and Chlorine Between Biocyclo(2,2,1)Heptane and t-Butyl Chloride. J. Am. Chem. Soc. 1946, 68, 195-196.

15. Zakharkin, L. I.; Okhlobystin, O. Y.; Semin, G. K.; Babushkina, T. A. Exchange of Hydrogen for Chlorine in the CarboraneCarbon Tetrachloride or Chloroform System under the Action of Aluminum Chloride. Izvestiya Akademii Nauk SSSR, Seriya Khimicheskaya 1965, 10, 1913-1914.

16. Kerrigan, J. V. The Interaction of Boron Trichloride with Diborane. Inorg. Chem. 1964, 3, 908-910.

17. Kondo, M.; Nishi, I.; Okamoto, K.; Kato, T.; Izumiya, N. Studies on Detection of Intramolecular Hydrogen Bonds by Hydrogen-Chlorine Exchange Method. Peptides, Synthesis, Structure, Function. Proceedings of the 7th American Peptide Symposium; Madison, Wisconsin, 1981; pp 291-294.

18. Frisch, M. J.; Trucks, G. W.; Schlegel, H. B.; Scuseria, G. E.; Robb, M. A.; Cheeseman, J. R.; Montgomery, J. A., Jr.; Vreven, T.; Kudin, K. N.; Burant, J. C.; Millam, J. M.; Iyengar, S. S.; Tomasi, J.; Barone, V.; Mennucci, B.; Cossi, M.; Scalmani, G.; Rega, N.; Petersson, G. A.; Nakatsuji, H.; Hada, M.; Ehara, M.; Toyota, K.; Fukuda, R.; Hasegawa, J.; Ishida, M.; Nakajima, T.; Honda, Y.; Kitao, O.; Nakai, H.; Klene, M.; Li, X.; Knox, J. E.; Hratchian, H. P.; Cross, J. B.; Adamo, C.; Jaramillo, J.; Gomperts, R.; Stratmann, R. E.; Yazyev, O.; Austin, A. J.; Cammi, R.; Pomelli, C.; Ochterski, J. W.; Ayala, P. Y.; Morokuma, K.; Voth, G. A.; Salvador, P.; Dannenberg, J. J.; Zakrzewski, V. G.; Dapprich, S.; Daniels, A. D.; Strain, M. C.; Farkas, O.; Malick, D. K.; Rabuck, A. D.; Raghavachari, K.; Foresman, J. B.; Ortiz, J. V.; Cui, Q.; Baboul, A. G.; Clifford, S.; Cioslowski, J.; Stefanov, B. B.; Liu, G.; Liashenko, A.; Piskorz, P.; Komaromi, I.; Martin, R. L.; Fox, D. J.; Keith, T.; Al-Laham, M. A.; Peng, C. Y.; Nanayakkara, A.; Challacombe, M.; Gill, P. M. W.; Johnson, B.; Chen, W.; Wong, M. W.; Gonzalez, C.; Pople, J. A. Gaussian 2003; Gaussian Inc.: Wallingford, CT.

19. Scott, A. P.; Radom, L. Harmonic Vibrational Frequencies: An Evaluation of Hartree-Fock, Moller-Plesset, Quadratic Configuration Interaction, Density Functional Theory, and
Semiempirical Scale Factors. J. Phys. Chem. 1996, 100 16502-16513.

20. Faustov, V. I.; Baskir, E. G.; Biryukov, A. A. Thermal Isomerization of Acetylnitrene: A Quantum-Chemical Study. Rus. Chem. Bull. Int. Ed. 2003, 52, 2328-2333.

21. Paul, D. F.; Haberfield, P. Chlorination of Anilines. Bimolecular Acid-Catalyzed Rearrangement of N-Chloroanilines. J. Org. Chem. 1976, 41, 3170-3175.

22. Depuy, C. H. An Introduction to the Gas Phase Chemistry of Anions. Int. J. Mass Spectrom. 2000, 200, 79-96.

23. Morel, G.; Seux, R.; Foucaud, A. Halogenation of Various $\alpha$-Carbonyl Carbanions by Carbon Tetrachloride. Bull. Soc. Chim. France 1975, 7/8, 1865-1870.

24. Staneke, P. O.; Groothuis, G.; Ingemann, S.; Nibbering, N. M. M. The Interplay Between Electron Transfer and Attack on Halogen in Gas-Phase Reactions of Negative Ions with Fluoro-Chloromethanes and Fluoro-Bromomethanes. Int. J. Mass Spectrom. 1995, 149/150, 99-110.

25. Staneke, P. O.; Groothuis, G.; Ingemann, S.; Nibbering, N. M. M. Competing Electron Transfer, Proton Abstraction, and Nucleophilic Substitutions in Gas-Phase Reactions of (Radical) Anions with Chloro- and Bromomethanes. J. Phys. Org. Chem. 1996, 9, 471-486.

26. Moran, S.; Ellis, H. B.; Defrees, D. J.; Mclean, A. D.; Ellison, G. B. Carbanion Spectroscopy: $\mathrm{CH}_{2} \mathrm{CN}^{-}$. J. Am. Chem. Soc. 1987, 109, 5996-6003.

27. Dispert, H.; Lacmann, K. Negative Ion Formation in Collisions Between Potassium and Fluoro- and Chloromethanes: Electron Affinities and Bond Dissociation Energies. Int. J. Mass Spectrom. Ion Phys. 1978, 28, 49-67.

28. Buncel, E.; Dust, J. M. Carbanion Chemistry: Structures and Mechanisms; Oxford University Press and American Chemical Society: Washington DC and New York, 2003; p 41.

29. Jonczyk, A.; Kwast, A.; Makosza, M. Reactions of Organic Anions. 89. Reactions of Carbon Tetrachloride with Carbon Acids in Catalytic Two-Phase System. J. Org. Chem. 1979, 44, 1192-1194. 